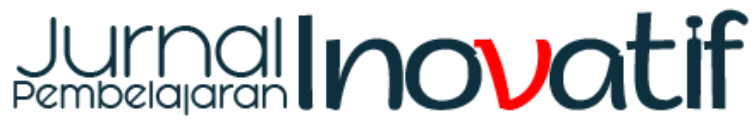 \\ http://iournal.uni.ac.id/uni/index.php/ipi
}

\section{Pengembangan Video Simulasi Konseling Teknik Dispute Cognitive Untuk Meningkatkan Resiliensi}

\author{
Reni Oktora Tarigan, ${ }^{\natural}$ Wirda Hanim $^{2}$, RA. Murti Kusuma Wirasti ${ }^{2}$ \\ ${ }^{1}$ Universitas Negeri Jakarta, Jakarta, Indonesia. \\ ${ }^{2}$ Universitas Negeri Jakarta, Jakarta, Indonesia. \\ 3 Universitas Negeri Jakarta, Jakarta, Indonesia. \\ DOI: https://doi.org/10.21009/JPI.031.01
}

\begin{abstract}
Article History
\section{Abstrak}

Received : 2020

Accepted : 2020

Published : 2020

$\overline{\text { Penelitian ini bertujuan untuk mengembangkan video simulasi teknik dispute cognitive }}$ untuk meningkatkan resiliensi. Metode penilitian yang digunakan adalah penelitian dan pengembangan ( $\mathrm{R} \& \mathrm{D})$ yang dikembangkan oleh Bergman dan Moore. Pengembangan video simulasi menggunakan metode Interactive Video (IVD) yang

\section{Keywords}

Counselors 1; dispute cognitive technique 2; resilience 3; simulation video 4 ; terdiri dari enam tahap, yakni (1) analisis, (2) desain, (3) pengembangan, (4) produksi, (5) pengarangan, (6) validasi. Desain ini dikembangkan berdasarkan hasil analisis kebutuhan mengenai perlunya video yang menggunakan teknik dispute cognitive. Video simulasi konseling yang berisikan simulasi proses konseling mulai dari contoh kasus, tahapan dalam konseling, hingga kesimpulan. Video ini telah diuji oleh ahli materi dan media. Hasilnya, menurut ahli materi video ini mendapatkan predikat Layak dengan skor $68 \%$. Sementara ahli media menyatakan sangat layak dengan memberikan skor $86 \%$. Selanjutnya dilakukan validasi oleh pengguna, Mereka memberikan skor $77,6 \%$ atau layak. Kesimpulannya adalah pengembangan video simulasi dengan teknik dispute cognitive layak dan dapat digunakan oleh guru bimbingan konseling dan diharapkan dapat membantu peserta didik untuk meningkatkan resiliensi.
\end{abstract}

\section{Abstract}

This research is aimed at developing simulation video using cognitive dispute technique for enhancing resilience. This research uses research and development (RED) which was developed by Bergman and Moore as its research method. Developing a simulation video using Interactive Video (IVD) method consists of six procedures, which are (1) analysis, (2) design, (3) development, (4) production, (5) authored and, (6) validation. The result of this research shows that counselors need media of simulation video particularly using cognitive dispute technique. Eventually, the research produces counseling simulation video consisting counseling process simulation from cases, steps of counseling, and summary. Moreover, the video can be played using any media players. Furthermore, this research invites material expert, media expert, and give space of user validation. The result of the research shows that of material expert assessment, its was the better predicate with a $68 \%$ score. Of the media expert assessment the predicate is very worthy with $86 \%$ score. Of the user validation, the video receives $77,6 \%$ which can be identified as the highest satisfaction level of the user. To sum up, the development of simulation video using dispute cognitive technique in this research is beneficial for counselors and can optimize the level of resilience enhancement. 


\section{PENDAHULUAN}

Peserta didik merupakan anggota masyarakat yang berusaha mengembangkan diri dan mereka merupakan sosok yang membutuhkan bantuan orang lain untuk dapat berkembang kearah dewasa. Peserta didik di jenjang sekolah menengah atas merupakan peserta didik yang memiliki motivasi belajar, hasrat meraih prestasi, ambisi, ekspresi, cita-cita, kemampuan berorganisasi, mampu merasakan dan menunjukkan rasa sedih, marah, senang, dan sebagainya. Mereka merupakan pribadi yang otonom yang ingin diakui keberadaannya.

Kemampuan setiap peserta didik dalam menghadapi tantangan pastilah berbeda, perbedaan tersebut biasanya disebabkan oleh cara pandang yang berbeda dalam menghadapi masalah. Salah satu faktor penyebab perbedaan tersebut yaitu resiliensi. Menurut Desmita ( dalam Fitriani, 2015 : 4 ) mengungkapkan resiliensi merupakan kemampuan mengambil makna dari setiap tantangan dan kegagalan yang dialami, serta mampu mengunakan pengalaman hidupnya tersebut untuk membangun cita-cita yang lebih tinggi. Sedangkan menurut Block (dalam Papalia, 2001) resiliensi merupakan tipe kepribadian dengan ciri-ciri kemampuan menyesuaikan diri yang baik, mandiri, percaya diri, pandai berbicara, penuh perhatian, suka membantu dan berpusat pada tugas. Grotberg (1999) dalam penelitiannya menjelaskan bahwa resiliensi sangat penting dalam membantu individu untuk mengatasi segala kesulitan yang muncul.

Permasalahan resiliensi pada peserta didik tingkat SMA perlu menjadi perhatian guru bimbingan konseling. Dalam memberikan bantuan penanganan permasalahan resilinesi pada peserta didik guru bimbingan konseling harus memiliki kemampuan dalam melakukan konseling. Salah satu pendekatan konseling yang harus dikuasai oleh guru bimbingan konseling untuk membantu peserta didik dalam meningkatkan resiliensi yaitu pendekatan Rational Emotif Behavior Theraphy. Pendekatan Rational Emotif Behavior Theraphy (REBT) adalah pendekatan behavior kognitif yang menekankan pada keterkaitan pikiran, perasaan, dan tingkah laku. Pendekatan ini dikembangkan pertama kali oleh Albert Ellis. Pendapat ini senada dengan hasil penelitain Fitriani (2016) bahwa penerapan teknik dispute cognitive dalam REBT untuk meningkatkan resiliensi pada peserta didik.

\footnotetext{
Menghadapi kondisi minimnya pemahaman dan kemampuan guru bimbingan konseling untuk meningkatkan resiliensi pada peserta didik, maka diperlukan langkah pengembangan secara maksimal. Guru bimbingan
}

konseling harus mampu secara adaptif terhadap situasi dan perkembangan masalah yang hadapi oleh para peserta didiknya. Media penyampaian yang menarik akan sangat berpengaruh dalam proses belajar mengajar. Hal tersebut senada dengan pandangan dari Hamalik (Azhar, 2003) yang menjelaskan bahwa penggunaan media pengajaran dalam proses belajar mengajar dapat meningkatkan minat dan keinginan yang baru, meningkatkan motivasi dan stimulan kegiatan belajar, dan bahkan membawa pengaruh-pengaruh psikologis terhadap pembelajar. Salah satu yang menjadi penting untuk disajikan dalam perkembangan zaman saat ini sebagai bentuk media pembelajaran adalah video simulasi.

Video merupakan perpaduan antara gambar bergerak yang disertai dengan audio (suara). Dengan kata lain video adalah perpaduan antara audio dan visual. Seperti yang didefinisikan oleh Azhar Arsyad (2011), bahwa video adalah gambar dalam frame, yang diproyeksikan pada lensa secara mekanis menampilkan gambar hidup. Dengan pertimbangan pola belajar dan efisiensi waktu belajar secara pribadi, pembelajaran menggunakan media video menjadi lebih menarik dan tepat guna dibandingkan dengan cara belajar dengan membaca atau teks. Dalam hal ini, video dapat menjadi media pembelajaran konseling.

Perkembangan teknologi, kemajuan zaman dan kebudayaan mendorong proses konseling dengan pendekatan REBT dan teknik dispute cognitive menjadi alternatif untuk aspek konseling khususnya resiliensi. Dengan demikian pula menjadi pendorong untuk dikembangkannya video simulasi konseling Teknik dispute cognitive dengan topik meningkatkan resiliensi.

\section{Kajian Teori}

\section{Resiliensi}

Resiliensi adalah gambaran dari proses dan hasil kesuksesan beradaptasi terhadap keadaan yang sulit atau pengalaman hidup yang yang memicu stres hingga trauma yang dalam (O'Leary \& Ickovics, 1995). Sementara itu, menurut Reivich dan Shatte. (2002) menjelaskan bahwa resiliensi adalah kemampuan untuk mengatasi dan beradaptasi terhadap kejadian yang berat atau masalah yang terjadi dalam kehidupan. Sedangkan pada tahun 1995, International Resilience Project, menyepakati definisi untuk resiliensi adalah (Dalam Esya Anesty Mahudi, 2016) adalah kemampuan individu atau kelompok untuk mencegah atau meminimalisir dampak dari sebuah masalah dan menunjukkan kekuatan dalam menghadapi permasalahan tersebut. 
Kemampuan resiliensi pada peserta didik mengalami perkembangan yang harus mendapatkan perhatian serius dari guru bimbingan konseling. Karena dalam berbagai kasus, sekolah kerap mengalami kesalahan atau kekeliruan dalam menanggulangi berbagai masalah atau hambatan emosional yang dialami oleh peserta didiknya. Permasalahan sosial yang terjadi dilingkungan keluarga seperti perceraian kedua orang tua, pertengkaran antar anggota keluarga, kesulitan ekonomi dan masalah keluarga sejenisnya. Faktor pemicu lainnya seperti kesulitan dalam bersosialisasi dengan teman, merasa memiliki kekurangan, hingga konflik sosial yang terjadi dalam lingkungannya. Hal ini pun dapat berdampak begitu variatif. Lebih jauh lagi, transformasi kebudayaan, keterbukaan informasi, perkembangan teknologi dan lemahnya kontrol sosial bagi perkembangan remaja-pun dapat berdampak negatif.

Uraian mengenai pentingnya perkembangan individu untuk mencapai kemampuan resiliensi yang tinggi juga diuraikan oleh Vygotsky (Slavin, 2000:270) menyatakan bahwa setiap individu berkembang dalam ranah sosial. Menurut Vygotsky, peserta didik sebaiknya diberikan pembelajaran oleh orang yang lebih tua maupun teman sebaya yang dinilai lebih mampu, atau yang disebut olehnya sebagai pemagangan kognitif.

Resiliensi dapat digunakan untuk berbagai hal seperti yang dipaparkan menurut Reivich dan Shatte (2002), yaitu a). Overcoming, mengubah cara pandang menjadi positif dan meningkatkan kontrol diri dalam kehidupan. b). Steering Through, menghilangkan beban dalam diri dan persaan negatif dengan meningkatkan keyakinan terhadap diri bahwa mampu menguasai lingkungannya. c). Bouncing Back, mengeluarkan diri dari pengalaman traumatik yang mengganggu kehidupan dengan cara menguasai kemampuan yang kuat untuk berhubungan dengan orang lain dalam upaya mengatasi tekanan dirinya. d). Reaching Out, berkomitmen untuk mengejar halhal baru sehingga mampu mendapatkan pengalaman hidup yang lebih kaya dan bermakna positif.

\section{Metode REBT dan Teknik Dispute Cognitive}

Pendekatan REBT pertama kali dipopulerkan dan dikembangkan oleh psikolog Albert Ellis (dalam Winkel, 2009). Metode konseling Rational Emotive Behavior Therapy atau REBT merupakan pendekatan behavior kognitif yang fokus pada hubungan antara perasaan, pikiran, dan tingkah laku. Dalam ranah konseling, metode REBT fokus pada tingkah laku. Namun demikian, karena REBT mendasari pada kinerja kognitif, emosi dan prilaku dalam diri individu. Sehingga REBT menjadi pendekatan yang bersifat individu. Dalam hal tersebut, Ellis dan Happer (Huchhinson \& Chapman, 2010) menyatakan REBT mengajari individu tentang bagaimana menghilangkan keyakinan irasional dan menggantinya dengan yang rasional untuk mengubah perilaku individu menjadi lebih baik.

Metode REBT bertujuan untuk mengajarkan kembali kepada konseli untuk memahami secara kognitif yang melahirkan pikiran irasional. Oleh karenanya, pendekatan REBT yang fokus pada individu adalah bersifat direktif. Menurut pandangan Ellis, "Pengalaman Aktif (A)" tidak langsung menyebabkan timbulnya "Akibat Emosional (C), namun tergantung pada "Belief System (B)".

Sementara itu, konselor memiliki tugas dan pekerjaan untuk menjadi pendidik, pengarah, mempengaruhi, sehingga dapat mengubah keyakinan dan pikiran irrasional menjadi pikiran rasional. Hal ini sangat berguna untuk proses konseling. Terutama bagi guru bimbingan konseling yang menghadapi murid usia remaja. Dalam mengoperasionalkan metode REBT, terdapat teknik yang harus dipahami dan dijalankan. Salah satu teknik dalam pendekatan REBT adalah Dispute cognitive.

Teknik Dispute cognitive merupakan teknik untuk melakukan dekonstruksi terhadap keyakinan atau pikiran seseorang. Dalam hal ini, lebih dekat pada upaya untuk menghancurkan pikiran atau keyakinan irrasional dan membangun keyakinan rasional di atas reruntuhan pikiran irrasional yang telah dihancurkan sebelumnya. Salah satu tindakan irrasional yang diidentifikasi oleh Albert Ellis (1979) adalah lari dari kesulitan dan tanggung jawab.

Permasalahan yang berhubungan erat dengan teknik dispute cognitive adalah resiliensi. Novi Fitriani (2016) menjelaskan bahwa teknik dispute cognitive dapat meningkatkan resiliensi pada mahapeserta didik. Adapun resiliensi yang meningkat pada aspek regulasi emosi, aspek control impuls, aspek optimis, aspek kemampuan menganalisis masalah, aspek empati, aspek efikasi diri dan aspek pencapaian. Sedangkan penelitian dari Esya A. Mashudi (2012) menjelaskan bahwa konseling REBT teruji efektif meningkatkan resiliensi pada remaja. Tidak hanya itu penelitian yang dilakukan oleh Joseph (2004) dan Neenan (2009) juga menunjukkan bahwa REBT mampu untuk meningkatkan resilensi.

\section{Video Simulasi}

Video berkenaan dengan apa yang dapat dilihat, terutama yaitu gambar hidup (bergerak; motion), proses perekamannya, dan penayangannya yang tentunya melibatkan teknologi. Video juga merupakan media komunikasi termasuk media 


\section{Reni Oktora Tarigan | JPI/Vol.o3/No.o1/202o H. o1 - o8}

pembelajaran yang sangat cepat ditangkap informasinya oleh manusia.

Dalam proses produksinya video memiliki tiga tahapan umum, yaitu 1). Penulisan, tahap ini diawali dengan penulisan cerita yang dikembangkan menjadi naskah cerita. Naskah cerita ini yang kemudian dikembangkan menjadi storyboard untuk memandu proses pengambilan gambar dan suara. 2). Pengambilan Gambar dan Suara, proses ini ditentukan oleh alur yang terdapat dalam storyboard . Baik gambar, suara, maupun dialog diambil melalui proses ini. 3). Pengolahan Hasil, setelah pengambilan gambar dan suara dilakukan maka hasil pengambilan tersebut kemudian ditransfer ke komputer untuk selanjutnya dilakukan proses editing. Proses editing berguna untuk menyempurnakan hasil pengambilan gambar. Setelah sempurna dalam proses editing kemudian file yang telah tersedia diubah menjadi format yang dibutuhkan, proses ini disebut juga dengan rendering. Proses terakhir adalah dengan melakukan proses Burn To Disc jika ingin video tersebut disimpan kedalam disc tertentu.

Penggunaan video sebagai sarana pembelajaran memberikan satu pengalaman baru kepada para pembelajar. Proses kegiatan belajar mengajar, fokus dan mempengaruhi emosi dan psikologi anak didik sangat diperlukan. Karena dengan hal tersebut peserta didik akan lebih mudah memahami pelajarannya. Tentunya media video yang disampaikan kepada anak didik harus bersangkutan dengan tujuan pemebelajaran. Hamalik (Azhar, 2003) menjelaskan penggunaan media pengajaran dalam proses belajar mengajar dapat meningkatkan keinginan dan minat yang baru, meningkatkan motivasi dan menstimulus kegiatan belajar, serta membawa pengaruh-pengaruh psikologis terhadap pembelajar. Penggunaan video sebagai media pengajaran pada tahap orientasi pengajaran sangat membantu keefektifan proses pembelajaran dan penyampaian pesan serta isi pelajaran pada saat itu.

Menurut Cheppy Riyana (2007) untuk mendapatkan video pembelajaran yang mampu membangkitkan motivasi dan efektivitas penggunanya maka pengembangan video pembelajaran harus memperhatikan beberapa kriteria dan karakteristik. Adapun karakteristik video pembelajaran yaitu, Kejelasan Pesan, Berdiri Sendiri, Bersahabat, Representasi Isi, Visualisasi dengan media, Resolusi Tinggi, Digunakan secara umum dan individual. Dengan kata lain, video pembelajaran harus memiliki unsur interaktif.

Bergman dan Moore (Gustafson dan Branch, 2002) secara khusus menciptakan hasil multimedia yang interaktif. Dalam modelnya, Bergman dan
Moore berisi enam kegiatan utama yaitu: analisis, desain, pengembangan, produksi, karangan, dan validasi. Adapun langkah-langkah yang akan dilakukan pada model video simulasi dari Bergman dan Moore adalah:

1. Tahap Analisis

2. Tahap Desain

3. Tahap Pengembangan

4. Tahap Produksi

5. Tahap Pengarangan

6. Tahap Validasi

Bagi guru BK metode dengan menggunakan video juga dapat memudahkan pendekatan REBT dan teknik dispute cognitive untuk dioperasionalkan. Hal ini akan membantu dalam proses konseling dalam meningkatkan resiliensi peserta didik.

\section{Metode Penelitian}

Penelitian ini menggunakan metode model penelitian dan pengembangan (R\&D). Penelitian dengan metode penelitian dan pengembangan dilakukan berdasarkan suatu model pengembangan yang berbasis industri, dengan memakai temuantemuannya untuk mendesain produk dan prosedur, kemudian secara sistematis dilakukan uji lapangan, dievaluasi, disempurnakan untuk memenuhi kriteria keefektifan, kualitas dan standar tertentu (Setyosari, 2010). Dalam hal ini penelitian R\&D menurut Borg dan Gall memiliki sepuluh tahapan, diantaranya: Studi Pendahuluan (Kajian Pustaka dan Survei Awal), perencanaan penelitian, pengembangan produk awal, uji lapangan terbatas (Preliminary field test), revisi hasil uji lapangan terbatas, uji lapangan lebih luas, revisi uji lapangan lebih luas, uji kelayakan (Operational field test), revisi hasil uji kelayakan, diseminasi dan sosialisasi produk akhir

Model pengembangan rancangan pengajaran berorientasi produk yang dipakai adalah model pengembangan interactive video (IVD) seperti yang dirancang oleh Bergman dan Moore (1990). Model Bergman dan Moore ini memiliki kesesuaian dengan penelitian dan pengembangan video simulasi model teknik dispute cognitive karena model itu mengarah pada bimbingan dan pengaturan produksi produk multimedia interaktif (Gustafron \& Branch, 2002).

Model pengembangan Bregman dan Moore (1990), seluruh kegiatan pengembangan Video simulasi model konseling teknik Dispute cognitive dapat diurai seperti dibawah ini: tahap analisis, tahap desain, tahap pengembangan, tahap produksi, tahap pengarangan, tahap validasi.

Populasi dalam penelitian ini adalah guru bimbingan dan konseling di DKI Jakarta. Sampel dalam penelitian ini terbagi atas beberapa subyek kelompok, 
yaitu seorang ahli materi, dan seorang ahli teknologi informasi, serta subyek uji coba yaitu guru bimbingan dan konseling yang telah bekerja sebagai konselor yang berjumlah lima orang.Penentuan subyek guru bimbingan dan konseling tersebut dilakukan dengan teknik purposive sampling.

Video semulasi model konseling teknik dispute cognitive dikembangkan dengan format video DVD. Produksi video simulasi model konseling teknik dispute cognitive dilakukan dengan aspect ratio 16:9 serta resolusi 720 x 480 . Materi video terdiri dari simulasi konseling dan penjabaran teori per sesi. Teknik pengumpulan data yang digunakan dengan assesmen kebutuhan. Dan teknik analisis data dilakukan untuk menganalisis hasil evaluasi oleh ahli sendiri/materi, ahli media, serta kelompok kecil pengguna akhir. Hasil evaluasi oleh ahli sendiri/materi, ahli media, serta kelompok kecil dilakukan dengan menggunakan rumus presentasi sebagai berikut (Riduwan, 2009

\section{$\%=\frac{\sum \text { skor evaluasi }}{\sum \text { skor } \text { ideal }} \times 100 \%$}

Selanjutnya kelayakan video simulasi model konseling teknik dispute cognitive dilakukan dengan menyesuaikan hasil perhitungan persentase terhadap tabel berikut (Suryaningsih, 2014):

Tabel 1 Kategori Penilaian Berdasarkan Persentase

\begin{tabular}{ll}
\hline Persentase & Penilaian \\
\hline o $\%>X \geq 20 \%$ & Sangat Tidak Layak \\
$\mathbf{2 0} \%>X \geq \mathbf{4 0} \%$ & Tidak Layak \\
$\mathbf{4 0} \%>X \geq 60 \%$ & Cukup \\
$\mathbf{6 0} \%>X \geq 80 \%$ & Layak \\
$\mathbf{8 0} \%>X \geq 100 \%$ & Sangat Layak \\
\hline
\end{tabular}

\section{Hasil dan Pembahasan}

Penelitian ini bertujuan untuk mengembangkan video simulasi dengan teknik dispute cognitive ini untuk meningkatkan resiliensi. Pengembangan video simulasi terdiri dari enam tahap pengembangan yaitu, tahap analisis, tahap desain, tahap produksi, tahap pengarangan dan tahap validasi. Video simulasi dengan pendekatan REBT teknik dispute cognitive dapat menjadi metode sekaligus media yang efektif untuk meningkat resiliensi. Video simulasi konseling ini merupakan bentuk dari media pembelajaran yang dapat digunakan oleh guru Bimbingan dan Konseling.

Peneliti sebelum melakukan studi pendahuluan melakukan analisis terhadap sumber daya manusia dan tujuan dari penggunaan video simulasi konseling. Penelitian ini juga melibatkan ahli konseling untuk memandu dalam penentuan topik permasalahan yang dapat diatasi dengan teknik dispute cognitive. Ahli konseling yang dilibatkan adalah dosen Bimbingan dan Konseling Universitas Negeri Jakarta.

Analisis kebutuhan yang dilakukan terhadap guru BK mengenai pemahamannya tentang teknik dan tahapan konseling dengan menggunakan teknik dispute cognitive. Hasilnya adalah bahwa sebanyak 40 orang $(40 \%)$ dari responden menyatakan mengetahui teknik konseling yang dapat digunakan untuk meningkatkan resiliensi peserta didik. Selain itu $86 \%$ atau 86 orang dari 100 orang responden mengetahui tahapan konseling pendekatan teknik dispute cognitive.

Mengetahui teknik dan tahapan konseling menggunakan teknik dispute cognitive bukan berarti mampu menerapkannya dengan baik. Hal tersebut tentu didasarkan dari implementasi yang berkelanjutan dari pengetahuan teoritis tersebut. Hal ini dibuktikan dengan data bahwa guru bimbingan dan konseling yang tidak mahir dalam menerapkan keterampilan teknik konseling dispute cognitive mencapai angka 52\%. Dari hasil analisis secara komprehesif tersebut, maka dapat ditarik kesimpulan dalam beberapa poin sebagai berikut: 1). Guru bimbingan dan konseling dalam upaya dan tugasnya dalam meningkatkan resiliensi pada para peserta didik sangat membutuhkan media simulasi konseling, khususnya yang dikembangkan dengan teknik dispute cognitive. 2). Dalam menunjang poin pertama maka dilakukan pengembangan media simulasi konseling dalam bentuk video simulasi untuk memandu penyelesaian dan menjelaskan tahap demi tahap dari proses peningkatan resiliensi melalui teknik dispute cognitive. 3). Guru bimbingan dan konseling merasa bahwa penggunaan video simulasi dengan teknik dispute cognitive sangat menarik dan dapat meningkatkan kemampuan dan menjadi penujang bagi kerja-kerja bimbingan dan konseling. 4). Terdapat beberapa hambatan dalam proses pengembangan teknik dispute cognitive, yaitu tentang pemahaman operasional dari teknik tersebut yang masih tergolong rendah, serta belum tersedianya fasilitas penunjang dan contoh pengembangan video simulasi tersebut. 5). Para guru bimbingan dan konseling menilai bahwa pengembangan dari video simulasi konseling teknik tersebut sangat diperlukan. 6). Terdapat kelemahan teknis dalam mengoperasikan komputer secara penuh. Mayoritas Guru BK mampu mengoperasikan program dasar dari komputer, namun merasa kesulitan jika terjadi permasalahan, termasuk sulit dalam mengoperasikan program pemutar media.

Berdasarkan hasil evaluasi pada tahap analisis. Maka peneliti melanjutkannya dengan pengembangan video simulasi dengan menggunakan teknik dispute cognitive pada tahap desain. Tahap ini dimulai dengan melakukan pengembangan proses konseling untuk meningkatkan resiliensi dan 
ancangan konseling dispute cognitive. Ada pun proses yang dilakukan yaitu dengan mengubah tulisan dan naskah cerita menjadi bentuk storyboard. Naskah cerita untuk pembuatan video hanya sebatas tulisan diubah menjadi sebuah alur cerita lengkap dengan gambar sketsa untuk membantu dan memandu proses pengambilan gambar. Pada tahap desain video simulasi konseling teknik dispute cognitive disimpan dalam bentuk digital video disc (DVD) dengan format $\mathrm{MP}_{4}$ berkapasitas 4,05 GigaByte (GB). Selanjutnya penelitian dilanjutkan dengan masuk pada tahap pengembangan.

Tahap pengembangan dimulai dengan menyusun ancangan dan skrip konseling sesuai dengan pendekatan REBT teknik dispute cognitive melalui media Microsoft Word. Dari penyusunan skrip tersebut kemudian dilakukan pengembangan story board. Diakhir tahap ini kemudian dilakukan kembali evaluasi dengan daftar centang. Proses ini ditujukan untuk melakukan verifikasi kembali pada hasil tahap pengembangan. Pasca dilakukan evaluasi, tahap pengembangan siap dilanjutkan pada tahap produksi.

Tahap produksi terbagi menjadi tiga bagian, praproduksi, produksi dan pasca produksi. Pada tahap praproduksi dilakukan penentuan lokasi pembuatan video konseling dan penentuan pemeran dalam video simulasi.

Produksi video simulasi konseling teknik dispute cognitive adalah proses penciptaan video dengan melibatkan kedua pemeran. Dalam menunjang pembuatan video ini digunakan beberapa alat utama dan pendukungnya, antara lain, Kamera Video Nex 10o, Nikon d75o, dan Cannon 6od, beserta peralatan pendukungnya yaitu, Lampu LED dan Clip On Senheizer.

Peneliti membuat video dalam bentuk/format MP4 (h264).108op yang berisikan simulasi konseling teknik dispute cognitive dengan tema meningkatkan resiliensi pada peserta didik. Peneliti tidak hanya membuat video simulasi, namun juga mengembangkan buku panduan untuk memutar video simulasi konseling serta mempelajari teknik konseling yang ditampilkan dalam bentuk sesi per sesi. Langkah selanjutnya dalam tahap produksi adalah melakukan penyuntingan master video denganprogram Adobe Premiere Pro CC 2017 setelah memperoleh masukan dari seorang ahli media. Sementara itu, Spesifikasi PC yang digunakan dalam kegiatan pasca produksi adalah MSI FX $400 \mathrm{CPU}$ Intel ${ }^{\circledR}$ CoreTM i3 Processor, OS Windows 7 Pro 64- bit, CHIPSETIntel ${ }^{\circledast} \mathrm{HM}_{55}$, Memory DDR 3 1066, RAM $8 \mathrm{~GB}$.

Setelah tahap produksi, kemudian dilanjutkan dengan tahap pengarangan. Dalam tahap ini, peneliti melakukan kerja untuk mengubah video menjadi bentuk Digital Video Disc (DVD) dengan format $\mathrm{MP}_{4}$.Dalam proses tersebut digunakan programAdobe Premiere Pro CC 2017.

Tahap akhir dari proses tersebut adalah tahap validasi. Tahap ini melibatkan tiga unsur utama, yaitu ahli materi, ahli media dan pengguna. Validasi ahli materi merupakan upaya dari peneliti dengan melibatkan seorang ahli materi untuk melakukan evalusasi terhadap video simulasi konseling yang telah diproduksi. Evaluasi dilakukan untuk melihat kesesuaian antara teori dan kegunaan dari video simulasi konseling teknik dispute cognitive dalam meningkatkan resiliensi pada peserta didik. Hasilnya diperoleh nilai prosentase (P) sebesar 68\%. Hasil tersebut didapat dari dibaginya skor hasil pengumpulan data sebesar 68 dengan skor ideal 10o, kemudian dikalikan dengan $100 \%$.

Tabel 2 Kategori Penilaian Berdasarkan Persentase

\begin{tabular}{ll}
\hline Interval Persentase & Kategori \\
\hline $\mathbf{0} \%>$ skor $\geq \mathbf{2 0} \%$ & Sangat Tidak Layak \\
$\mathbf{2 0} \%>$ skor $\geq \mathbf{4 0} \%$ & Tidak Layak \\
$\mathbf{4 0} \%>$ skor $\geq \mathbf{6 0} \%$ & Cukup \\
$\mathbf{6 0} \%>$ skor $\geq \mathbf{8 0} \%$ & Layak \\
$\mathbf{8 0} \%>$ skor $\geq \mathbf{1 0 0} \%$ & Sangat Layak \\
\hline
\end{tabular}

Dengan skor sebesar $68 \%$ maka video simulasi konseling teknik dispute cognitive dalam meningkatkan resiliensi pada peserta didik dapat dikategorikan Layak. Artinya, materi yang terdapat dalam video simulasi konseling telah sesuai dengan teori konseling pendekatan REBT dan teknik dispute cognitive untuk meningkatkan resiliensi pada peserta didik.

Ahli media juga melakukan validasi dengan meilbatkan dua orang ahli media dari Universitas Negeri Jakarta. Dari hasil evaluasi ahli media pertama didapatkanskor hasil pengumpulan data sebesar 75 atau setara dengan 88,2\%. Sedangkan dari ahli media yang kedua didapatkan skor hasil pengumpulan data sebesar 73 atau setara dengan $86 \%$. Dari kedua hasil validasi ahli media tersebut jumlah presentase yang didapatkan yaitu sebesar 
$87 \%$ yaitu Indikator dalam mengkonversi hasil penghitungan tersebut adalah sebagai berikut:

Hal ini menunjukan bahwa dengan mendapatkan skor sebesar $87 \%$ maka hasil uji ahli media menunjukan video simulasi konseling yang dibuat masuk pada kategori Sangat Layak. Sedangkan dalam proses validasi pengguna menunjukan hasil skor yang diperoleh adalah sebesar $77,6 \%$. Skor presentase tersebut menunjukkan bahwa video simulasi konseling teknik dispute cognitive sangat layak digunakan oleh guru bimbingan dan konseling untuk meningkatkan resiliensi para peserta didiknya. Berdasarkan hasil tersebut juga menunjukan bahwa bagi pengguna video simulasi tersebut sangat mudah untuk dipelajari dan dipahami serta sangat membantu sebagai media bimbingan dan konseling dalam meningkatkan resiliensi peserta didik.

\section{SIMPULAN}

Berdasarkan pada hasil penelitian tentang pengembangan video simulasi konseling dengan teknik dispute cognitive pada peningkatan resiliensi diperoleh beberapa kesimpulan. Penelitian ini menunjukan adanya kebutuhan dari guru bimbingan dan konseling mengenai media pembelajaran untuk bimbingan dan konseling khususnya dalam rangka meningkatkan resiliensi. Para guru bimbingan dan konseling juga merasa perlu untuk terus mengembangkan video simulasi konseling dan diberikan contohnya. Sedangkan penelitian ini menghasilkan video simulasi konseling dengan teknik dispute cognitive. Video tersebut berisikan simulasi proses konseling mulai dari contoh kasus, tahapan dalam konseling dan kesimpulan. Pelibatan ahli materi, media dan kelompok pengguna digunakan dalam proses validasi produk video simulasi. Sehingga dapat melahirkan produk video simulasi yang sesuai dengan dasar teori dengan penilaian sangat layak, serta bermanfaat, dan edukatif.

Penelitian ini juga melahirkan beberapa saran untuk pengembangan khazanah ilmu pengetahuan. Di antaranya adalah:

1. Bagi guru bimbingan dan konseling, dapat terus memperluas pemahaman dan referensi dasar mengenai topik penelitian, khususnya tentan pendekatan REBT dan teknik dispute cognitive.

2. Bagi mahasiswa program studi bimbingan dan konseling, harus memiliki kemampuan untuk terus mengembangkan teknik disputecognitive dalam pengayaan bidang keilmuannya.

3. Bagi siswa, dapat meningkatkan resiliensi dan prestasi akademiknya dengan memaksimalkan program bimbingan konseling melalui video simulasi teknik dispute cognitive.

4. Bagi sekolah, lebih memperhatikan aspek dorongan serta memfasilitasi program bimbingan dan konseling dengan secara keras memaksimalkan ketersediaan fasilitas penunjang untuk memajukan kinerja dari para guru bimbingan konseling.

5. Bagi para peneliti untuk penelitian selanjutnya, Memperkuat hasil produk berupa video simulasi konseling dengan penjelasan yang lebih padat tentang permasalahan resiliensi dan memperbaiki tampilan dasar dari video agar lebih mudah dioperasikan. Tantangan untuk dapat lebih menyederhanakan produk berupa video dan membuat buku pedoman untuk memandu pengguna dalam proses penggunaanya.

\section{DAFTAR PUSTAKA}

Anesty, E, M.(2012). Konseling Rasional Emotif Behavior Untuk Meningkatkan Resiliensi Remaja. UPI: Tidak diterbitkan.

Arief, S., Sadiman Et.al. (2009). Media Pendidikan:Pengertian,Pengembangan dan Pemanfaatannya. Jakarta: PT. Raja Grafindo Persada.

Bergman,R.E., \& Moore, T.V.(1990). Managing interactive video / multimediaprojects . Englewood Cliffs, NJ:Educational Technology Publications

Castro, Veronica, Johnson, Michael.B, \& Smith, Robert. (2011). Self-Reported Resilient Behaviours of Seventh and Eighth Grade Students Enrolled in an Emotional Intelligence Based Program. University of Texas Pan American

Corey, G. (2009). Teori dan Praktek Konseling. Bandung: PT Refika Aditama.

Desmita. (2009). Mengembangkan Resiliensi Remaja Dalam Upaya Mengatasi Stress Sekolah. Jurnal : Ta'dib Vd.12, No. 1.

Fitriani, Devitasari \& Nursalim, Moch. (2015). Penerapan RAP untuk Meningkatkan Resiliensi Peserta didik Kelas X SMK N 1 Cerme, Gresik. UNS.

Ellis, A. (1979). Rational emotive behavior therapy and its applications to emotional education. In A. Ellis \& S. Blau (Eds.), The Albert Ellis reader: A guide towell-being using rational emotive behavior therapy (pp. 253-260). New Jersey: Citadel Press.

Gufron, M. Nur, dan Rini Risnawati (2012).TeoriTeori Psikologi. Yogyakarta : Ar-Ruzz Media

Grotberg, E.(1999). A Guide To Promoting Resilience In Children: Strengthening The Human Spirit. Bernard Van Leer Fondation 
Reni Oktora Tarigan | JPI/Vol.o3/No.01/2020 H. o1 - 08

Gladding, Samuel,T. (1992).Konseling (Profesi Yang Menyeluruh). Jakarta: Indeks

Neenan, Michael. (2009). Developing Resilience, A Cognitive Behavioral Approach. New York : Routledge

Slavin, R.E., (200o). Educational Psychology : Theory and Practice, Edisi 6, Boston: Allyn and Bacon.

Sugiyono .(2010). Metode penelitian kuantitatif, kualitatif, dan $R$ and D. Bandung: Alfabeta

Sukiman.(2012). Pengembangan Media Pembelajaran. Yogyakarta: Pedajogja

Taylor, L.(1993). Vygotskian influences in mathematics education, with particular reference to attitude development, Vol. 15, Pages 3 -7. 